\title{
Occurrence of acanthocephalans in Teleost fishes of Gemlik Bay, Sea of Marmara, Turkey
}

\author{
M. Ç. OĞUZ1 ${ }^{1}$ Y. KVACH ${ }^{2}$ \\ ${ }^{1}$ Biology Department, Faculty of Science and Arts, Ataturk University, 25240 Erzurum, Turkey; ${ }^{2}$ Odessa Branch of \\ the Institute of Biology of the Southern Seas, NAS of Ukraine, Vul. Pushkinska 37, 65011 Odessa, Ukraine, \\ E-mail:quach@paco.net
}

\begin{abstract}
Summary
The fish acanthocephalan fauna of Turkish waters is poorly known. In this study 8 fish species (Merluccius merluccius, Trachurus trachurus, Uranoscopus scaber, Gobius niger, G. cobitis, Scorpaena scrofa, Eutrigla gurnardus, Solea vulgaris) were collected from Gemlik Bay and examined for their acanthocephalan fauna. Four species not previously recorded in fish of Turkish waters were found: Solearhynchus soleae (Echinorhynchidae), Acanthhocephaloides propinquus, Paracanthocephaloides kostylewi (Arhythmacanthidae), and Longicollum pagrosomi (Pomphorhynchidae). The most common species was A. propinquus, a parasite that infects mostly gobiids (G. niger, G. cobitis). Longicollum pagrosomi was a new record for the Mediterranean basin.
\end{abstract}

Key words: acanthocephalans; morphology; fishes; Sea of Marmara; taxonomy

\section{Introduction}

Although many studies of acanthocephalans have been conducted in various locations in the Mediterranean basin, Turkish waters are little studied (Altunel, 1983; Oğuz, 1991; Akmirza, 2002). The aim of this study was to conduct an investigation of acanthocephalan species in fishes of the Sea of Marmara, an area not previously investigated.

\section{Material and Methods}

The study area was the coastal waters of North-Western Anatolia, geographically located at $40^{\circ} 22^{\prime} \mathrm{N}, 28^{\circ} 52^{\prime} \mathrm{E}$, specifically Gemlik Bay in the Sea of Marmara (Fig. 1). A total of 236 fish belonging to eight species were caught with fyke and standard nets at various times of the years 1990 - 1993. The samples comprised the European hake Merluccius merluccius (L.) ( $\mathrm{n}=39$ ), the scad Trachurus trachurus $\mathrm{L} .(\mathrm{n}=39)$, the stargazer Uranoscopus scaber $\mathrm{L}$. $(\mathrm{n}=16)$, the black goby Gobius niger L. $(\mathrm{n}=28)$, the giant goby G. cobitis Pallas, $1811(\mathrm{n}=25)$, the scorpion fish Scorpaena scrofa L. $(\mathrm{n}=17)$, the grey gurnard Eutrigla gurnardus (L.) ( $\mathrm{n}=16)$, and the common sole Solea vulgaris Quensen, $1806(\mathrm{n}=56)$. The fish were placed live in plastic containers with regular seawater for transfer to the laboratory, where they were examined for acanthocephalans within 24 hours of capture. The alimentary canal was examined using stereomicroscopy $(\times 12$ and $\times 50)$.

Parasites were fixed with acetic acid/formaldehyde/ethanol solution (AFA) and stained with Mayer's carmalum. Voucher specimens were deposited in the parasitological collection of Ataturk University, Erzurum, Turkey.

Parasitological parameters used followed Bush et al. (1997): prevalence (P, \%), intensity range (IR), and mean intensity (MI) of infection.

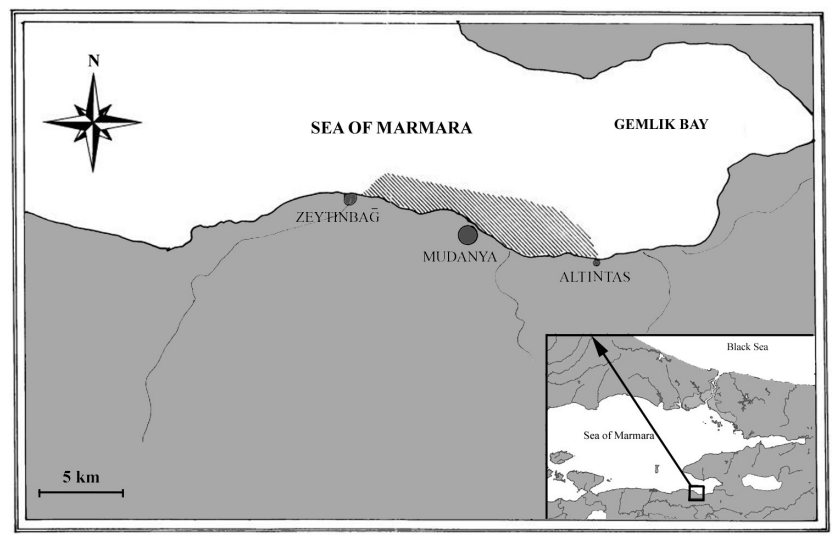

Fig. 1. Schematic map of the sample area

\section{Results}

Four acanthocephalan species belonging to three families were recovered from the host intestines. 
Family Echinorhynchidae (Cobbold, 1879)

Solearhynchus soleae (Porta, 1905)

Synonyms: Echynorhynchus soleae Porta, 1905, E. rhytidotes Monticelli, 1905, E. aurantiacus Monticelli, 1887 (?), E. corrugatus Monticelli, 1900, Acanthocephaloides soleae (Porta, 1905), A. rhytidotes (Monticelli, 1905) sensu Belofastova and Korniychuk, 2000.

Host: S. vulgaris (Tab. 1). Number of parasites collected: 10 (4 ڤึ, 6 우), number of parasites measured: 10. Voucher reference number: HWML 216145.

Diagnostic features: The body was 9464 (5382 - 20328) $\mu \mathrm{m}$ long and $728(693-1200) \mu \mathrm{m}$ wide (Tab. 2, Fig. 2).
The proboscis was $251(224-320) \mu \mathrm{m}$ long and the proboscis sac was $320(277-480) \mu \mathrm{m}$ long. There were $12-$ 14 rows of hooks on the proboscis each comprising $5-6$ hooks. The lemnisci were longer than the proboscis sac, measuring $348(312-350) \mu \mathrm{m}$ and $340(312-349) \mu \mathrm{m}$ long. The longest hooks were in the middle of the proboscis (Tab. 2). The smallest basal hooks were unrooted and resembled spines.

Males had two testes in the posterior part of the body (Fig. 2 ). They were distant from six piriform cement glands. The eggs measured $46(56-68) \mu \mathrm{m}$ long and $15(12-20) \mu \mathrm{m}$ wide.

Table 1. Distribution of acanthocephalan species in teleost fish from Gemlik Bay

\begin{tabular}{|c|c|c|c|c|c|c|}
\hline Host fish species & Parasite species & $\mathrm{N}$ & $\mathrm{N}_{\mathrm{i}}$ & $\mathrm{P}$ & MI & IR \\
\hline Merluccius merluccius & Acanthocephaloides propinquus & 39 & 8 & 20.5 & 4.1 & $1-16$ \\
\hline Trachurus trachurus & Longicollum pagrosomi & 39 & 2 & 5.2 & 1.5 & $1-2$ \\
\hline Uranoscopus scaber & A. propinquus & 16 & 1 & 6.2 & 1 & 1 \\
\hline Gobius niger & $-/ /-$ & 28 & 11 & 39.3 & 4.6 & $1-20$ \\
\hline G. cobitis & $-/ /-$ & 25 & 10 & 40 & 10.7 & $1-24$ \\
\hline Scorpena scrofa & $-/ /-$ & 17 & 7 & 41.2 & 2.8 & $1-2$ \\
\hline Eutrigla gurnardus & $-/ /-$ & 16 & 1 & 6.2 & 1 & 1 \\
\hline \multirow[t]{3}{*}{ Solea vulgaris } & Solearhynchus soleae & 56 & 6 & 10.7 & 1.6 & $1-3$ \\
\hline & A. propinquus & 56 & 11 & 19.6 & 1.7 & $1-11$ \\
\hline & Paracanthocephaloides kostylewi & 56 & 2 & 3.6 & 2.5 & $2-3$ \\
\hline
\end{tabular}

$\mathrm{N}$ - number of fishes examined; $\mathrm{N}_{\mathrm{i}}$ - number of fishes infected; $\mathrm{P}$ - prevalence (\%); $\mathrm{MI}$ - mean intensity; IR - intensity range (min-max)

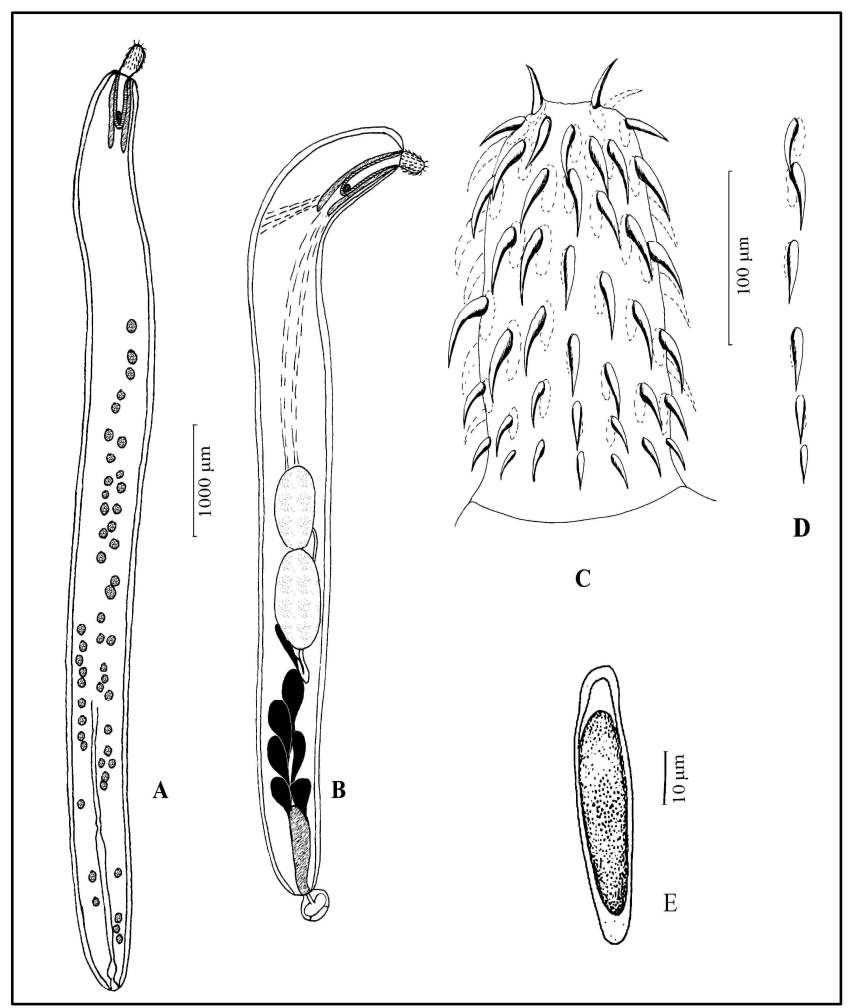

Fig. 2. Solearhynchus soleae. Host: Solea vulgaris. A - female in toto; $\mathrm{B}$ - male in toto; $\mathrm{C}$ - proboscis; $\mathrm{D}$ - hooks row; $\mathrm{E}$ - egg
Family Arhythmacanthidae (Yamaguti, 1935)

Acanthocephaloides propinquus (Dujardin, 1845) Meyer, 1933

Synonyms: Echinorhynchus propinquus (Dujardin, 1845), E. fabri (Rudolphi, 1819), E. globulosus (Rudolphi, 1819), E. pumilio (Rudolphi, 1819), E. scorpaenae (Rudolphi, 1819), E. zeni (Rudolphi, 1819)

Host: U. scaber, G. niger, G. cobitis, M. merluccius, S. scrofa, E. gurnardus, S. vulgaris (Tab. 1). Number of parasites collected: 223 , number of parasites measured: $50(25$


HWML 216142.

Diagnostic features: The body was $4054(2600-6237) \mu \mathrm{m}$ long and $182(140-280) \mu \mathrm{m}$ wide (Tab. 2, Fig. 3). The metasoma was covered with small cuticular spines 4.5 $(3.75-5.25) \mu \mathrm{m}$ long. The proboscis was cylindrical, 182 $(140-280) \mu \mathrm{m}$ long, armed with 12 rows of hooks each with $4-5$ (rarely 5 or $5-6$ ) rooted hooks. The middle hooks were longest, and the basal ones were smallest (Tab. 2 ). The lemnisci were longer than the proboscis sac. The proboscis sac was cylindrical and the ganglion was clearly visible in the base of the sac (Fig. 3).

The male copulatory bursa sucker was spherical with small suckers on its structure. The spherical testes occupied the middle part of the body (Fig. 3). There were six piriform posttesticular cement glands. Saefftigen's pouch was piriform. The uterus of the female was funnel-shaped and the selector cells were in clusters. The eggs were $56(30-64)$ 
Table 2. Mean measurements $(\mu \mathrm{m})$ of acanthocephalans from fishes of Gemlik Bay

\begin{tabular}{|c|c|c|c|c|c|c|c|c|}
\hline \multirow[t]{2}{*}{ Parameters } & \multicolumn{2}{|c|}{$\begin{array}{c}\text { Solearhynchus } \\
\text { soleae }\end{array}$} & \multicolumn{2}{|c|}{$\begin{array}{c}\text { Acanthocephaloides } \\
\text { propinquus }\end{array}$} & \multicolumn{2}{|c|}{$\begin{array}{c}\text { Paracanthocephaloides } \\
\text { kostylewi }\end{array}$} & \multicolumn{2}{|c|}{$\begin{array}{c}\text { Longicollum } \\
\text { pagrosomi }\end{array}$} \\
\hline & $0^{\pi}$ & q & $\pi$ & क & $0^{\pi}$ & क & $0^{\pi}$ & 우 \\
\hline $\begin{array}{l}\text { Body size } \\
\text { (length } \times \text { width) }\end{array}$ & $6115 \times 589$ & $14400 \times 935$ & $3490 \times 531$ & $4523 \times 670$ & $6583 \times 900$ & $7680 \times 889$ & $7300 \times 660$ & $10164 \times 478$ \\
\hline Proboscis length & 230 & 282 & 178 & 232 & 360 & 320 & 3542 & 5313 \\
\hline $\begin{array}{l}\text { Proboscis sac length } \\
\text { Hook length: }\end{array}$ & 320 & 277 & 406 & 372 & 750 & 628 & 350 & 1617 \\
\hline Apical & 27 & 29 & 59 & 58 & 30 & 25 & 34 & 42 \\
\hline Middle & 35 & 35 & 34 & 37 & 40 & 44 & 42 & 44 \\
\hline Basal & 45 & 49 & 15 & 15 & 74 & 78 & 61 & 70 \\
\hline Testes sizes (width $\times$ & ength): & & & & & & & \\
\hline Anterior & $338 \times 569$ & - & $277 \times 391$ & - & $240 \times 320$ & - & $216 \times 272$ & - \\
\hline Posterior & $288 \times 595$ & - & $274 \times 361$ & - & $240 \times 312$ & - & $216 \times 272$ & - \\
\hline $\begin{array}{l}\text { Egg size } \\
\text { (width } \times \text { length) }\end{array}$ & - & $15.0 \times 46.0$ & - & $13 \times 56$ & - & $6.8 \times 57.4$ & - & $34 \times 140$ \\
\hline
\end{tabular}

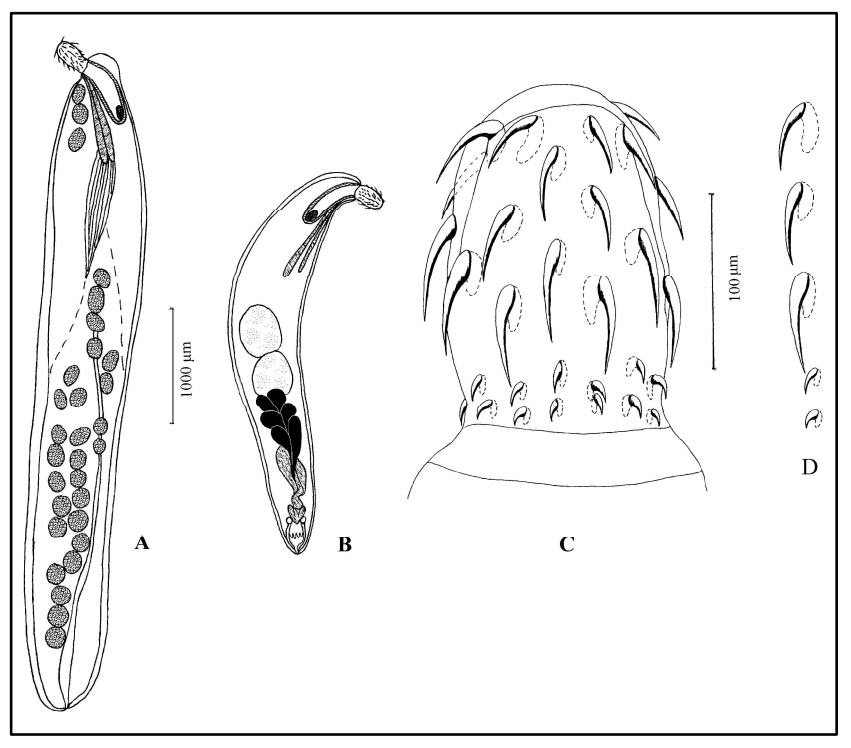

Fig. 3. Acanthocephaloides propinquus. Host: Gobius niger. A female in toto; $\mathrm{B}$ - male in toto; $\mathrm{C}$ - proboscis; $\mathrm{D}$ - hooks row

$\mu \mathrm{m}$ long and $13(10-16) \mu \mathrm{m}$ wide. Polarization was clearly visible in the secondary membrane of the eggs. The acanthor had one unrooted hook. The vitelline tube had a very thin membrane and the wide vagina was funnelshaped and short. There were four spender located on both sides of the vagina. The genital pores in both sexes were terminal.

Paracanthocephaloides kostylewi (Meyer, 1933)

Synonyms: Acanthocephaloides kostylewi Meyer, 1933, A. propinquus sensu Kostylew, 1926

Host: S. vulgaris (Tab. 1). Number of parasites collected: 3 (1 $\hat{0}, 2$ 9 ), number of parasites measured: 3 . Voucher reference number: MP9016A1-3.

Diagnostic features: The body was $7507(7404-7854) \mu \mathrm{m}$ long and 893 (739 - 1040) $\mu \mathrm{m}$ wide (Tab. 2, Fig. 4). The anterior part of the body was wider than the posterior. The proboscis was cylindrical, armed with 16 rows of hooks

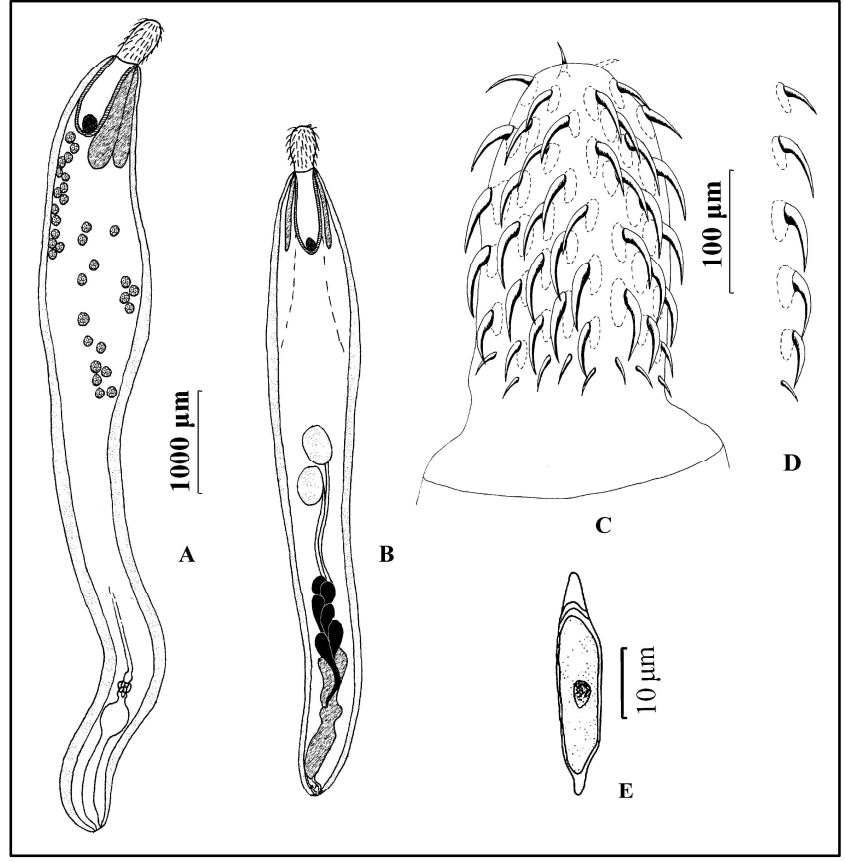

Fig. 4. Paracanthocephaloides kostylewi. Host: Solea vulgaris. A female in toto; $\mathrm{B}$ - male in toto; $\mathrm{C}$ - proboscis; $\mathrm{D}$ - hooks row; $\mathrm{E}$ egg

each with $5-6$ hooks the longest hooks being in the middle of the proboscis (Tab. 2). The smallest basal spinelike hooks were unrooted.

The testes were located centrally in the body distant from the cement glands (Fig. 4). There were six cement glands and a well-developed Saefftigen's pouch. The vitelline tube possessed well-developed selector cells. The eggs measured $57.4(42-64) \mu \mathrm{m}$ long and $17.0(12-20) \mu \mathrm{m}$ wide.

Family Pomphorhynchidae (Yamaguti, 1938)

Longicollum pagrosomi (Yamaguti, 1935)

Host: T. trachurus (Tab. 1). Number of parasites collected: ( $2 \hat{\jmath}, 1$ ) , number of parasites measured: 3 . Voucher re- 
ference number: MP9016A 5-6.

Diagnostic features: The body was 7300 (5036 - 10164) $\mu \mathrm{m}$ long and $660(478$ - 878) $\mu \mathrm{m}$ wide (Tab. 2, Fig. 5). The proboscis was cylindrical and wider anteriorly. It was $3542(2310-5313) \mu \mathrm{m}$ long and armed with $11-12$ rows of hooks comprising $11-13$ hooks in each. The anterior hooks were smaller than the posterior, measuring 34 (24 42) $\mu \mathrm{m}, 42(40-44) \mu \mathrm{m}$, to $61(54-70) \mu \mathrm{m}$ long. The short proboscis sac consisted of two membranes. The lemnisci were level with the proboscis. One immature male sample had two spherical testes, $216 \times 272 \mu \mathrm{m}$ in diameter. The copulatory bursa was $80 \times 140 \mu \mathrm{m}$. The cement glands were indistinct. The eggs measured $140(70-210) \mu \mathrm{m}$ long and $34(17-52) \mu \mathrm{m}$ wide.

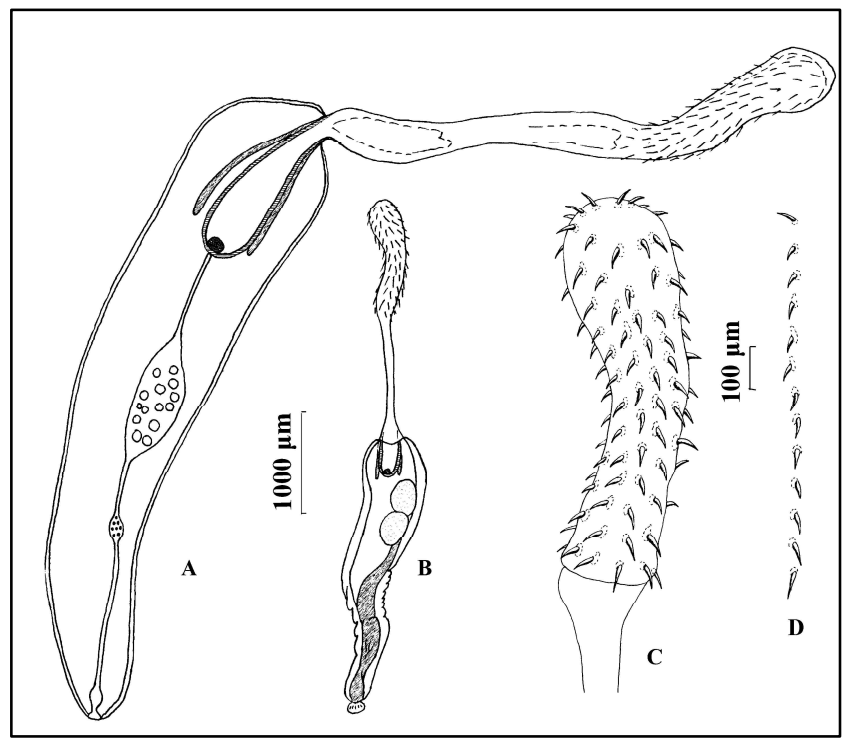

Fig. 5. Longicollum pagrosomi. Host: Trachurus trachurus. $\mathrm{A}$ - female in toto; $\mathrm{B}$ - male in toto; $\mathrm{C}$ - proboscis; $\mathrm{D}$ - hooks row

\section{Discussion}

Solearhynchus soleae, described as Echinorhynchus soleae from sole, Solea impar, in the Mediterranean Sea was later re-described by Meyer (1933) as Acanthocephaloides soleae. De Buron and Maillard (1985) placed it in the genus Solearhynchus (Echinorhynchidae). This species was recorded in the Black Sea by Belofastova and Korniychuk (2000) (as Acanthocephaloides rhytidotes).

Acanthocephaloides propinquus, was the most common species in this study (Tab. 1). It is common in marine and brackish water areas of the Mediterranean basin where it has been found in gobies in coastal lagoons of France by Parukhin (1976), de Buron et al. (1986), Sasal et al. (1996, 2000, 2001), de Buron and Chauvet (2003). A. propinquus has been recorded in the Adriatic (Radujković, 1989; Dezfuli, et al., 1992, 1996) and the Black Sea (including the Sea of Azov) (Pogoreltseva, 1952; Solonchenko, 1982; Naideno-va, 1974; Kvach, 2002a-c). In Atlantic waters, $A$. propin-quus was found off the Moroccan coastal waters by
Belhgyti et al. (1994), and near Galicia by Sanmartin et al. (2000a-b, 2001), Alvares et al. (2002).

The main hosts for this species are gobiid fishes (Dujardin, 1845, named this acanthocephalan "Echin. des gobies"). Black and giant gobies are most abundantly infected in the Sea of Marmara (Tab. 1). The morphology of the worms was similar to that of the Black Sea specimens. In the North-Western Black Sea, A. propinquus has the proboscis armed with 12 rows of hooks each with $4-5$ hooks (Golvan, 1969; Kvach, 2002a, c). Mediterranean specimens have $5-6$ hooks in each of 12 rows (de Buron et al., 1986; Dezfuli et al., 1992). Radujković (1989) mentioned those found in gobiids of the waters off Montenegro, Adriatic Sea, having 4-6 hooks in each row.

According to Kvach (2002a), the malacophagous round (Neogobius melanostomus) and monkey (N. fluviatilis) gobies are less infected with $A$. propinquus than the grass goby Zosterisessor ophiocephalus, which feeds mostly on crustaceans (Smirnov, 1986). De Buron and Chauvet (2003) stated that the intermediate host of $A$. propinquus is the amphipod, Caprella acutifrons. However, this amphipod is not significant in the goby diet. It is possible other crustaceans are intermediate hosts for $A$. propinquus.

$P$. kostylewi was first reported by Kostylew (1926) as Echinorhynchus propinquus in the snouted sole, S. nasuta, (Pallas, 1811) caught off the Crimean coast. Later, Meyer (1933) described this species as Acanthocephaloides kostylewi. Bray et al. (1988) placed this species in the genus Paracanthocephaloides because of the lack of cuticular spines. This species is found in the snouted sole in the Black Sea and Sea of Azov (Chernyshenko, 1947; Rădulescu, 1948; Solonchenko, 1982; Florescu \& Ieniştea, 1984). It is also found in the grass goby (Florescu \& Ieniştea, 1984). de Buron et al. (1986) noted that male reproductive structures occupied the posterior third of the body (similar to Paracanthocephaloides incrassatus). Also Paracanthocephaloides kostylewi was characterised as a "small species". In the present study the testes of this species were centrally located (Fig. 5) in agreement with Kostylew's (1926) observations. The body was large (Tab. 2) in agreement with the data of Chernyshenko (1947) who gave the length as $4500-10000 \mu \mathrm{m}$.

The Far-Eastern acanthocephalan L. pagrosomi was first described in fish from the Mediterranean basin. The specimens from the Sea of Marmara were smaller (Tab. 2) than those described by Yamaguti (1935) from fish in Japanese waters. This is due to the fact that the scad is a host of immature specimens of L. pagrosomi (Yamaguti 1935). The intermediate hosts for this species are amphipods (Yamaguti, 1935).

Other acanthocephalans have been recorded previously in Turkish waters. Neoechinorynchus agilis (Rudolphi, 1819) (Neoechinorhynchida: Neoechinorhynchidae) is recorded in a study on grey mullets (Mugilidae) from the Aegean Sea (Altunel, 1983). This is a typical parasite of mugilids in the Mediterranean basin and Far-Eastern waters. Another study off Gökçeada Island revealed Acanthocephalus lucii (Müller, 1776) (Echinorhynchida: Echinorhynchidae) 
in the annular gilthead, Diplodus annularis (L.), the scorpion fish, Scorpaena porcus (L.), and the perch, Perca fluviatalis (L.), (Akmirza, 2002). This limnetic Euro-Siberian species is atypical for marine fishes. However, in brackish waters of the Black Sea basin this parasite occurs in gobiids. For example, in Sebastopol Bay and the Khadzibey Estuary (Kostylew, 1926; Kvach, 2000c). Telosentis exiguus von Linstow, 1901 (Polymorphida: Illiosenthidae) is recorded in flounder, Pleuronectes flesus luscus (Pallas, 1811), from the Ekinli Lagoon connected to the Sea of Marmara (Oğuz, 1991). This parasite has a Mediterranean origin.

Although several studies have been conducted on A. propinquus, few references were found mentioning the other acanthocephalan parasites recorded in this study. Four acanthocephalan species, not previously recorded in fishes of Turkish marine waters, and one species, L. pagrosomi, found for the first time in the Mediterranean basin, have been confirmed.

\section{References}

AkmirzA, A. (2002): Acanthocephala and Cestoda Parasites Fishes Caught Near Gökçeada. Acta Parasitol. Turcica, 26: 93 - 98 (in Turkish)

Altunel, F. N. (1983): Parasites of mugilid fishes (Mugil spp.). Ege University, Faculty of Science, J. Series B: 364 -378 (in Turkish)

Alvarez, F., Iglesias, R., Parama, A., I., Leiro, J., SANMARTIN, M. (2002): Abdominal macroparasites of commercially important flat fishes (Teleostei: Scophthalmidae, Pleuronectidae, Soleidae) in Northwest Spain. Aquaculture, 213: $31-53$

Belghyti, D., Berrada-Rkhami, O., Boy, V., Aguessa, P., GABrion, C. (1994): Population biology of two helminth parasites of flat fishes, from the Atlantic Coast of Morocco. J. Fish Biol., 44: 1005 - 1021

Belofastova, I. P., KoRniYCHUK, J. M. (2000): New data about Acanthocephala from the Black Sea fishes. Ekologiya Morya, 53: 54 - 58 (in Russian)

Bray, R. A., SPEncer Jones, M. E., Lewis, J. W. (1988): Acanthocephaloides cyrusi n. sp. (Acanthocephala: Arhythmacanthidae) from southern African teleost fishes. System. Parasitol., 12: $109-116$

DE Buron, I., Chauvet, C. (2003): Étude comparée de l'acanthocéphale Acanthocephaloides propinquus dans deux espèces de gobies de l'étang de Thau (Hérault, France). In Combes, C. et Jourdane, J. (Eds): Taxonomie, écologie et évolution des métazoaires parasites. Vol. 1, PUP, Perpignan

DE Buron, I., Maillard, C. (1985): Acanthocéphales de pleuronectiformes Méditerranéens (Golf de Lion). 1. Création du genre Solearhynchus (Palaeacanthocephala). Ann. Parasitol. Hum. Comp., 60: 205 - 210

DE BurOn, I., RENAUD, F., EUZET, L. (1986): Speciation and specificity of acanthocephalans. Genetic and morphological studies of Acanthocephaloides geneticus sp. nov. parasitizing Arnoglossus laterna (Bothidae) from the Me- diterranean littoral (Sète - France). Parasitology, 92: 165 171

Bush, A. O., Lafferty, K. D., Lotz, J. M., Shostak, A. W. (1997): Parasitology meets ecology on its own terms: Margolis et al. revisited. J. Parasitol., 83: 575 - 583

CHERNYSHENKO, A. S. (1947): Materials on parasite fauna of fishes of the Gulf of Odessa. PhD Thesis, Odessa University, Odessa (in Russian)

DEZFULI, B. S., BoldRINI, P., Rossi, R. (1992): A morphological study of Acanthocephaloides propinquus (Acanthocephala) parasites of Gobius niger from the Northern Adriatic Sea. Parassitologia, 34: 203 - 204

Dezfuli, B. S., FranzoI, P., CArrieri, A., Rossi, R. (1996): Occurrence of acanthocephalan parasites in fishes from a coastal lagoon of the River Po. Crangon, 1: 25 - 30 Florescu, B.-I., IENIŞTEA, M.-A. (1984): Aperçu sur les Acanthocéphales de Roumanie (Acanthocephala). Trav. Mus. Hist. Natur. "Grigore Antipa», 25: 7 - 46

Golvan, Y. J. (1969): Systématique des acanthocéphales (Acanthocephala Rudolphi 1801). L'Ordre de Palaeacanthocephala Meyer, 1931. La super-famille de Echinorhynchoidae (Cobbold 1874) Golvan et Houin, 1963. Mém. Mus. Nat. Hist. Natur., Série A, Vol. 57: 1 - 373

Kostylew, N. N. (1926): Zur Kenntnis der Acanthocephalen der fische des Schwarzen Meeres. Zool. Anz., 67: $177-$ 183

KVACH, Y. (2002a): Helminths parasiting gobies and other fishes in the Budaksky Lagoon, Ukraine (Black Sea). Oceanol. Stud., 31: $59-65$

KVACH, Y. (2002b): Helminthes of goby fish of the Hryhoryivsky Estuary (Black Sea, Ukraine). Vestn. Zool., 36: 71 $-76$

KVACH, Y. (2002c): Acanthocephalans of some goby species (Gobiidae) of the Odessa Bay and lagoons and estuaries of the North-Western Black Sea. Ekologiya Morya, 61: 21 - 24 (in Russian)

Meyer, A. (1933): Acanthocephala. In Bronns, H. G. (Ed.): Klassen und Ordnungen des Tierreichs, T. 4, Bch. 2, Akademische Verlagsgesellschaft M.B.H., Leipzig

NAIDENOVA, N. N. (1974): Parasite fauna of fishes of Gobiid family of the Black Sea and Sea of Azov, Naukova Dumka, Kiev (in Russian)

OĞUZ, M. Ç. (1991): A parasitological investigation on flounders (Pleuronectes flesus luscus L. 1758) which were caught in Ekinli Lagoon. Turkish J. Zool., 15: 150 - 163 (in Turkish)

PARUKHIN, A. M. (1976): Parasite worms of the commercial fishes of the southern seas, Naukova Dumka, Kiev (in Russian)

Pogoreltseva, T. P. (1952): Materials on parasite fauna of fishes of the northeastern part of the Black Sea. Pratsi Instytutu Zoologii, 8: 100 - 120 (in Ukrainian)

RADUjKović, B. M. (1989): Parasites des poissons marines du Monténégro: Acanthocéphales. Acta Adriat., 30: 189 194

RĂDULESCU, I. (1948): Contribuţiuni la cunoaşterea parasitilor peştilor din Marea Neagră țărmul românesc. Anal. Inst. Cerc. Piscic. Rom., 3: $282-309$ 
Sanmartin, M. L., Alvarez, F., Peris, D., Iglesias, R., LEIRO, J. (2000a): Parasite Community study of the undulate ray Raja undulata in the Ria of Muros (Galicia, Northwest, Spain). Aquaculture, 184: 189 - 201

Sanmartin, M. L., Alvarez, F., Peris, D., Iglesias, R., LEIRO, J. (2000b): Helminth parasite communities of the conger eel in the estuaries of Arousa and Muros (Galicia, North-West Spain). J. Fish Biol., 57: 1122 - 1133

Sanmartin, M. L., Alvarez, F., Peris, D., Iglesias, R., LEIRO, J. (2001): Helminth parasite of black goby, Gobius niger in the Arousa and Muros estuaries on the northwest coast of Spain. Rev. Parasitol., 61: $24-30$

Sasal, P., FalieX, E., Morand, S. (1996): Parasitism of Gobius bucchichii Steindachner, 1870 (Teleostei, Gobiidae) in protected and unprotected marine environments. $J$. Wildl. Dis., 32: $607-613$

RECEIVED August 2, 2005
Sasal, P., Joblet, E., Faliex, M. S. (2000): Sexual competition in an acanthocephalan parasite of fish. Parasitology, 120: $65-69$

Sasal, P., Faliex, E., DE Buron, I., Morand, S. (2001): Sex discriminatory effect of Acanthocephalan, Acanthocephaloides propinquus on a gobiid fish Gobius bucchichii. Parasite, 8: $231-236$

SMIRNOV, A. I. (1986): Perch-likes (gobiids), scorpionfishes, flatfishes, clingfishes, anglerfishes. In: Fauna Ukrainy. Vol. 8, Issue 5, Naukova Dumka, Kiev. (In Russian)

SOLONCHENKO, A. I. (1982): The helminth fauna of fishes of the Sea of Azov. Naukova Dumka, Kiev (in Russian) YAmaguTI, S. (1935): Studies of the helminth fauna of Japan. Part 8. Acanthocephala. Jap. J. Zool., 6: 317 - 351 